\title{
Integrating Dendrochronology, Climate and Satellite Remote Sensing to Better Understand Savanna Landscape Dynamics in the Okavango Delta, Botswana
}

\author{
Jane Southworth ${ }^{1, *}$, Lesley Rigg ${ }^{2}$, Cerian Gibbes ${ }^{3}$, Peter Waylen ${ }^{1}$, Likai Zhu ${ }^{1}$, \\ Shannon McCarragher ${ }^{2}$ and Lin Cassidy ${ }^{4}$
}

1 Department of Geography and the Land Use and Environmental Change Institute (LUECI), University of Florida, TUR 3141, PO Box 117315, Gainesville, FL 32611, USA;

E-Mails: prwaylen@ufl.edu (P.W.); likaizhu@ufl.edu (L.Z.)

2 Department of Geography, Northern Illinois University, Davis Hall 601, DeKalb, IL 60115, USA; E-Mails: 1rigg@niu.edu (L.R.); smccarragher@niu.edu (S.M.)

3 Department of Geography and Environmental Studies, University of Colorado, 1420 Austin Bluffs Parkway, Colorado Springs, CO 80918, USA; E-Mail: cgibbes@uccs.edu

4 Okavango Research Institute (ORI), Maun, Botswana;

E-Mail: lincassidyconsulting@gmail.com

* Author to whom correspondence should be addressed; E-Mail: jsouthwo@ufl.edu; Tel.: +1-719-255-3534; Fax: +1-719-255-4066.

Received: 19 September 2013; in revised form: 16 October 2013 / Accepted: 6 November 2013 / Published: 20 November 2013

\begin{abstract}
This research examines the integration and potential uses of linkages between climate dynamics, savanna vegetation and landscape level processes within a highly vulnerable region, both in terms of climate variability and social systems. We explore the combined applications of two time-series methodologies: (1) climate signals detected in tree ring growth, from published literature, chronologies from the International Tree-Ring Data Bank, and minimal preliminary field data; and (2) new primary production (NPP) data of vegetation cover over time derived from remotely sensed analyses. Both time-series are related to the regional patterns of precipitation, the principle driver of plant growth in the area. The approach is temporally and spatially multiscalar and examines the relationships between vegetation cover, type and amount, and precipitation shifts. We review literature linking dendrochronology, climate, and remotely sensed imagery, and, in addition, provide unique preliminary analyses from a dry study site located on the outer limit of the Okavango Delta. The work demonstrates integration across the different data sources, to
\end{abstract}


provide a more holistic view of landscape level processes occurring in the last 30-50 years. These results corroborate the water-limited nature of the region and the dominance of precipitation in controlling vegetation growth. We present this integrative analysis of vegetation and climate change, as a prospective approach to facilitate the development of long-term climate/vegetation change records across multiple scales.

Keywords: dendrochronology; time-series analysis; NPP; precipitation; savanna

\section{Introduction}

At a global scale, climate is the main controlling factor determining the distribution of plant (and ultimately animal) communities. Global average temperatures have increased by approximately $0.7{ }^{\circ} \mathrm{C}$ in the past century [1], most likely due to anthropogenic emissions related to fossil fuel burning. Global climate models (GCMs) predict increases in global temperatures of $1.4{ }^{\circ} \mathrm{C}-4.5{ }^{\circ} \mathrm{C}$ during 1990-2100 [1]. Although the magnitude of increase is comparable to that experienced during the Holocene, the time over which it will occur is significantly shorter [2]. At the time scale of thousands of years plant communities are highly responsive to changes in global climate, but the rapidity of the current change may exceed species' ability to shift in the same manner as they have in the past $[2,3]$.

In North America during the Holocene, global temperature increases [4] led to well documented changes in plant species distributions and the poleward migration of tree species [5,6]. In Africa, vegetation shifts are also apparent in the pollen record [7,8]. Evidence from southern Africa suggests that evergreen and deciduous forests dominated during the moister interglacials, shifting to woodlands and savanna during arid glacial periods [9]. Post-glacial dynamics include dramatic forest decline during repeated dry spells since approximately 3500 years BP, shifting to grass savanna and miombo woodlands [10]. Hyrax midden pollen indicate a dramatic increase in karoid vegetation associated with relatively dry conditions during the past 300 years [11].

Given the response of vegetation to climate over the last 10,000 years, it is certain that vegetation distributions will be altered significantly by anthropogenic climate change within the next few centuries. However, in the short term of years to decades, species migration or community shifts will not be the immediate effects. Individual species' responses will likely be dominated to a greater extent by changes in annual growth rates and alterations in competition and reproductive success (seed production, seedling germination, etc.) leading to subtle changes in vegetation structure and composition as varying species respond favorably or adversely to climate change $[6,12]$.

African savannas are by nature highly heterogeneous mixed woody-herbaceous systems $[13,14]$. The existence of savanna ecosystems is closely related to non-equilibrium environmental variability [15]. They occupy multiple states in which changes in climate influences savanna functioning, and movement between states at the landscape scale is dependent primarily upon precipitation-vegetation relationships [16,17]. A hotly debated question is whether landscape change in southern African savannas represents irreversible "degradation" [18]. Degradation is a subjective term that does not necessarily reflect decreases in ecosystem productivity, but instead is situation specific [19-21]. In southern African savannas, changes labeled "degradation" [22] are usually associated with changes in 
vegetation structure including increases in density of woody species and shifts from grass- and tree-dominated landscapes (grass savanna) to less biologically productive shrub-dominated ones (woodland). This modification has been observed throughout southern Africa [23-25] and the causal factor to which it is most commonly attributed is human management decisions. However, precipitation also exerts considerable influence, especially in landscapes experiencing mean annual precipitation (MAP) of $650 \mathrm{~mm}$ or less [26,27]. The study region of the Okavango Delta, in southern Africa encompasses such an area and fieldwork focuses on the terminal region of the delta system. The region is composed of a savanna dryland ecosystem which currently receives sufficiently sparse MAP to ensure that precipitation is the dominant driver of vegetation dynamics [28]. The exact nature of this key driver of vegetation in the semi-arid landscape needs to be better understood in general in order to furnish information to land managers to improve recognition of the limitations and potential of their landscapes. Within the study region and broader semi-arid region there is a significant lack of information regarding the response of tree species to changing environmental conditions, emphasizing the need for data collection in this understudied region which paradoxically is also one of the areas identified as being most vulnerable to droughts under future climate scenarios.

Spatio-temporal trends of vegetation change can be measured at landscape-scales and over relatively extended temporal scales (past 30 years) using time series of remotely sensed data. Protracted desiccation and increased frequency of dry years may irreversibly alter the state of the savanna landscape. These associations have considerable effects on phenology, land use choices, and ultimately, socio-ecological functioning. An understanding of the long-term response of vegetation to climate change requires repeated spatial and temporal information on the distribution of vegetation. Since long term and instrument-acquired climate records in this region are spatially and temporally limited, the importance of proxy data for modeling current vegetation/climate dynamics and future potential vegetation shifts or states is magnified [28]. Pollen data from sediment cores [7,9] provide long-term reference data, and isolated midden pollen allow for "snap-shots" of landscape level vegetation patterns [11], but tree ring data have the potential to provide annual resolution and species-specific responses to climate [28]. In the last decade work on tropical dendrochronology has shown that many species do have the potential for long chronology development, quantifiable tree ages, and the development of growth models [29]. In southern Africa the strong seasonality of precipitation and deciduous habit of many species support the development of visible and measurable growth rings [28,30-34].

This paper furthers understanding of the potential of tree rings in this region of the world, employing limited tree cores of our own in combination with available tree ring data from surrounding regions. The data illustrate the possibility of creating a local chronology with established linkages to historic climate data and potentially also link this to the spatial and temporal characteristics of remotely sensed landscape-level vegetation dynamics. Specifically, we employ tree ring analysis to compare local species-specific growth response with instrumental climate records since the 1950s in order to elucidate the role of precipitation in controlling growth rates of our key species. The objectives are twofold: (1) To establish the potential for use of dendrochronology across this region to link plant growth with regional precipitation patterns, based predominantly on the literature and published dendrochronologies, but also linked to limited tree cores we collected of a locally dominant tree species; and (2) To link landscape-level vegetation measures of the past 30 years of monthly time 
series analysis, used to model annual NPP, derived from remotely sensed data, to tree growth and larger regional precipitation patterns. This study uniquely consolidates available information for this region of the world and develops a path forward for continued research in climate-vegetation dynamics of savanna systems.

\subsection{Study Area}

The Okavango catchment (Figure 1) ranges in size from 3,000 to $16,000 \mathrm{~km}^{2}$ dependent upon precipitation and inundation patterns. Our study area is focused on the southern portion of this much larger basin, an area with relatively low population density, and away from river inundation and flooding, such that the only moisture input to the trees we study is local precipitation. This semi-arid region is defined by scarce annual precipitation and high interannual variability (coefficient of variation), and experiences mean annual precipitation (MAP) between 350 and $650 \mathrm{~mm} / \mathrm{yr}$ [35-37]. Kalahari sands constitute the dominant soils throughout. The inception of a period of reduced precipitation in the late 1970s correlates to a noted shift in global climate and decreased precipitation over much of southern Africa, possibly in connection to a coupling of the El Niño-Southern Oscillation (ENSO) and the Indian Ocean Di-pole [38-42].

Figure 1. Study area located in southern Africa. The landscape scale analysis examines the terminus of the Okavango Delta and is combined with an analysis of tree cores collected west of the delta.
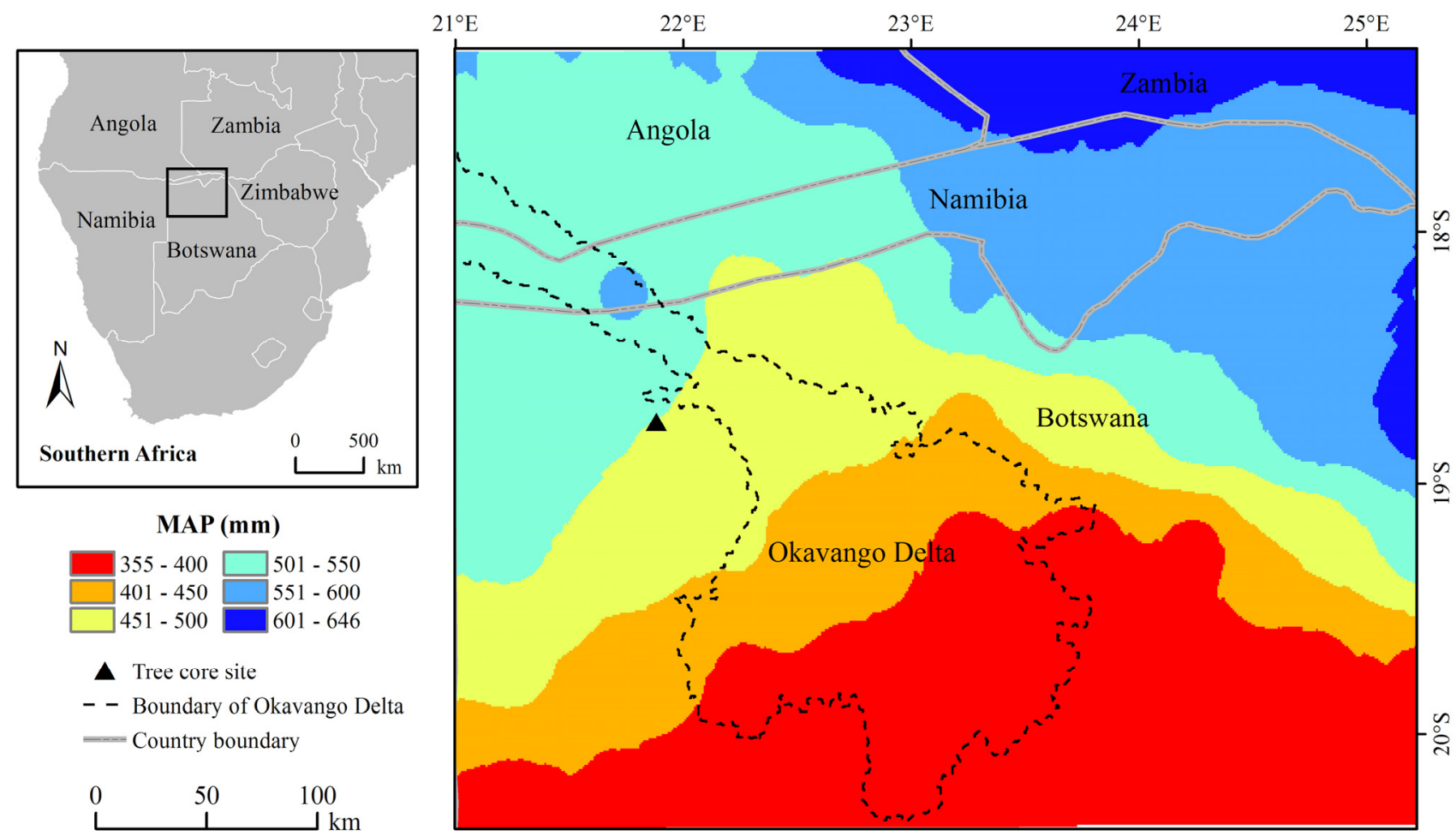

Precipitation variability is apparent at three dominant temporal scales; intra-annual, inter-annual and inter-decadal, all of which may well interact in a non-linear fashion. The principle controls on precipitation are the meridional shift of the inter-tropical convergence zone (ITCZ) and the moisture delivered by the associated airmasses. MAP is primarily a function of the length of time the area is 
under the influence of the ITCZ and is related to the coefficient of variation in the common inverse fashion. The study area lies directly to the west of Zimbabwe, one of the regions identified early in the study of global impacts of ENSO $[43,44]$. Lag cross-correlations of annual precipitation and the Southern Oscillation Index (SOI) reveal a spatially consistent, but not statistically strong, positive relationship - drought in warm phases of ENSO and excess rains in cold, consistent with previous research [45]. Recent research [42] indicates that, the strength of the association with the ENSO signal in eastern portions of the study area is contingent upon the state of the Indian Ocean Dipole/zonal mode (IODZM) and that the various epochal coupling and uncoupling of these two major atmosphere-ocean forcings, have considerable impact on precipitation variability.

\section{Materials and Methods}

\subsection{Precipitation Data}

When addressing changes across the broader region, the gridded precipitation dataset, with 0.5 degree grids size, from the University of Delaware (1951-2005) is utilized [46]. This gridded data is modeled using station observations and the Shepard interpolation algorithm [46]. It uses a spatial interpolation of monthly total precipitation station values created a $0.5^{\circ} \times 0.5^{\circ}$ degree latitude/longitude grid with grid nodes centered on $0.25^{\circ}$ which results in a total of 232 points for the OKZ catchment. However, due to the spatial variability of precipitation in this region the Shakawe climate station data (1937-2007) were also utilized for specific comparisons to the tree core data. This monthly precipitation data was collated to water year (October-September) to present the mean annual precipitation data presented here.

\subsection{Regional Dendrochronology}

In June 2011, 20 samples (cores $n=18$, cross sections $n=2$ ) were collected opportunistically from 10 common savanna tree species in Botswana (Figure 2) for the purpose of evaluating the dendrochronological potential of the region's dominant tree species. Knowledge of the existence of clear growth rings is a key prerequisite, prior to the future collection of sufficient samples to create a full chronology that can be compared with confidence to climate and remotely sensed data. Samples were dried in the field and prepared for analysis upon return to Illinois. Tree cores were prepared using standard dendrochronological techniques $[47,48]$, including cutting, mounting, polishing and minimal wetting in lieu of staining and then examined under a stereo-zoom microscope in the Tree Ring Laboratory at Northern Illinois University.

Only two species were identified as suitable for further collection and analysis (Table 1); Pterocarpus angolensis $(\mathrm{n}=3)$ and Burkea africana $(\mathrm{n}=1)$, both of which are known from the literature (i.e., Fitchler et al. (2004) [28]). Cores identified for potential climate correlation analysis ( $P$. angolensis) were examined by two individuals who independently marked ring boundaries (Figure 3) based upon the pattern of early wood to late wood (weak ring porous vessel distribution at start of growth season; Fitchler et al. (2004) [28]). Using only the cores for which rings were clearly visible and the ring boundaries reliably determined, annual ring widths were measured to within 
$0.01 \mathrm{~mm}$ (Velmex UniSlide Tree Ring System) and the cores visually cross-dated as the sample size was only three.

Figure 2. Field collection of tree cores by Dr. Lesley Rigg, for later lab dendrochronology analysis.

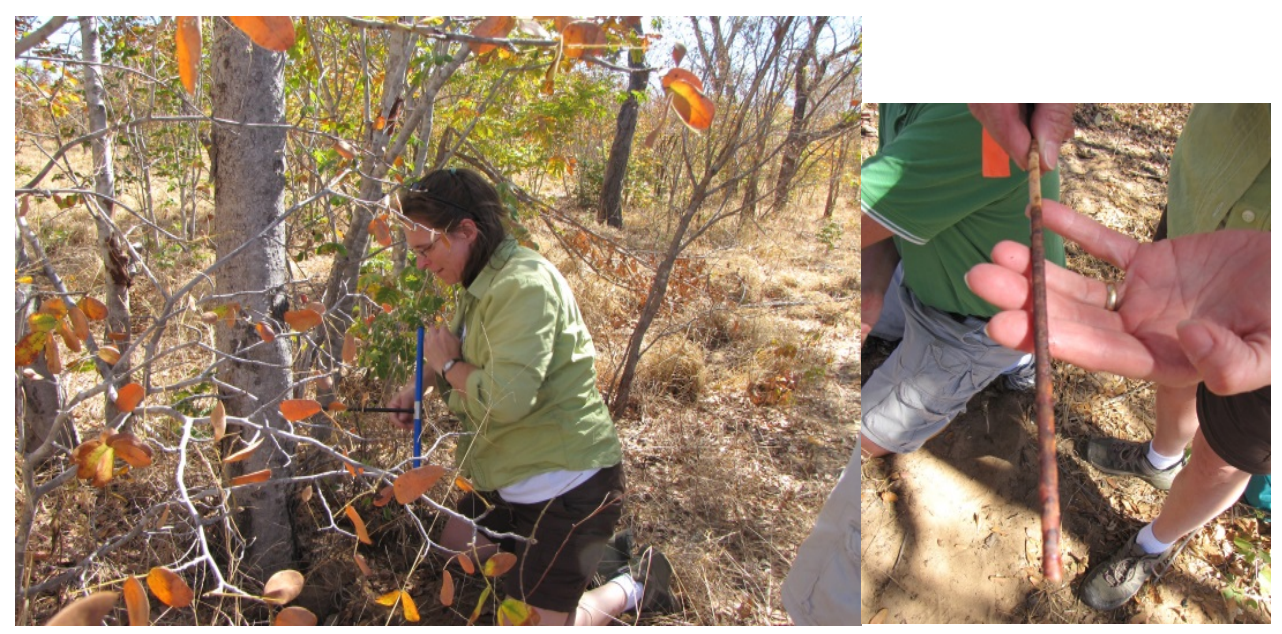

Table 1. Species sampled in the study site, June 2011, n represents the number of trees cored for each species.

\begin{tabular}{|c|c|c|c|c|}
\hline Species & $\begin{array}{c}\text { Common } \\
\text { Name } \\
\end{array}$ & $\mathbf{n}$ & $\begin{array}{c}\text { Avg. DBH } \\
\text { (cm) }\end{array}$ & Measurable Ring Structure \\
\hline Acacia tortilis & Umbrella thorn & 3 & 20.7 & $\begin{array}{l}\text { no (rings inconsistently distinct so } \\
\text { not measureable }{ }^{* *} \text { ) }\end{array}$ \\
\hline Colophospermum mopane & Mopane & 3 & 41.1 & no \\
\hline Pterocarpus angolensis & Mokwa & 3 & 45 & yes \\
\hline Brachystegia sp. & & 2 & 33.7 & $\begin{array}{l}\text { no (rings inconsistently distinct so } \\
\text { not measureable) }\end{array}$ \\
\hline Lonchocarpus nelsii & $\begin{array}{l}\text { Kalahari apple } \\
\text { leaf }\end{array}$ & 2 & 29.2 & no \\
\hline Acacia nigrescens & knobthorn & 1 & - & no core extracted-too dense \\
\hline Baikiaea plurijuga & Rhodesian teak & 1 & 43.4 & no \\
\hline Boscia albitrunca & Shepherd's tree & 1 & 41.9 & no \\
\hline Burkea africana & Wild Seringa & 1 & - & yes \\
\hline Croton magalobotrys & $\begin{array}{l}\text { Large } \\
\text { Fever-berry }\end{array}$ & 1 & 41.5 & no \\
\hline Lonchocarpus capassa & Raintree & 1 & $>50$ & no \\
\hline
\end{tabular}

* One core and two cross sections. ${ }^{* *}$ Ring margins exist, though sporadically throughout the wood, and thus cannot be measured from year to year.

The normal procedure within dendrochronology is to cross-date cores, detrend for decreasing growth with time and, if possible, create a site chronology. The intention of this study was not to create a site chronology from trees sampled, but rather determine the potential to create such a chronology using species within the study site. Due to the exploratory nature of the field collection and the 
resulting low sample size, our examination of the regional dendrochronology potential for this work draws upon and integrates current literature (Table 2) in the region and published tree chronologies from the International Tree-Ring Data Bank.

Figure 3. Ring structure of Pterocarpus angolensis (stereo-zoom microscope). Arrows illustrate the clarity of the tree rings and direction of growth.

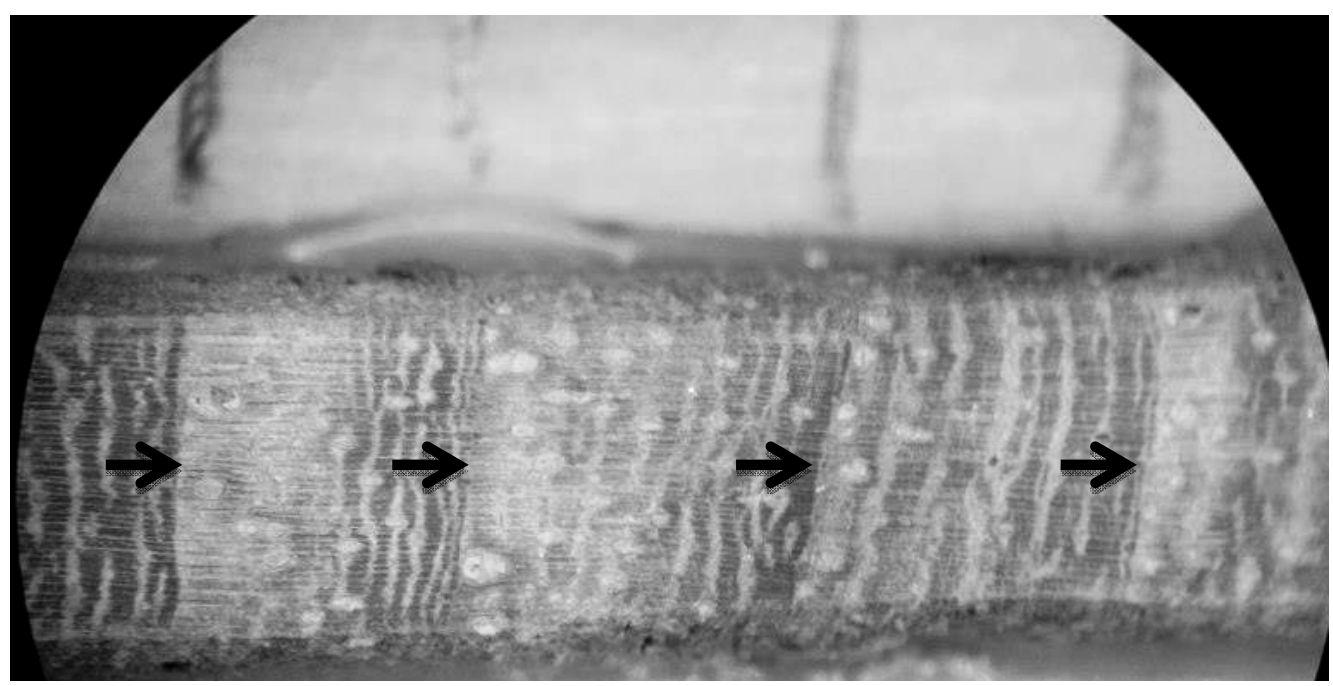

Table 2. Dendroclimatological potential for several locally common species in southern Africa.

\begin{tabular}{|c|c|c|c|c|c|}
\hline Species & Location & $\begin{array}{c}\text { Correlated Climate } \\
\text { Variable (Ring Widths } \\
\text { and Climate) }\end{array}$ & $\begin{array}{c}\text { Longest } \\
\text { Chronology } \\
\text { (Years) }\end{array}$ & $\begin{array}{c}\text { Chronology } \\
\text { Sample Depth } \\
\text { (\#Stems) } \\
\end{array}$ & Authors \\
\hline \multirow[t]{3}{*}{$\begin{array}{l}\text { Pterocarpus } \\
\text { angolensis }\end{array}$} & Zimbabwe & $\begin{array}{l}\text { Summer rainfall; ENSO; } \\
\text { Decadal droughts }\end{array}$ & 201 & 36 & $\begin{array}{l}\text { Therrell et al. } \\
2006[31]\end{array}$ \\
\hline & Zimbabwe & Rainfall (+) & 120 & 14 to 39 & $\begin{array}{l}\text { Stahle et al. } \\
1999[30]\end{array}$ \\
\hline & Namibia & $\begin{array}{l}\text { Rainfall }(+) \text {; } \\
\text { Temperature }(-) \text {; ENSO }\end{array}$ & 79 & 4 to 5 & $\begin{array}{l}\text { Fichtler et al. } \\
2004[28]\end{array}$ \\
\hline Burkea africana & Namibia & $\begin{array}{l}\text { Rainfall }(+) \text {; } \\
\text { Temperature }(-) \text {; ENSO }\end{array}$ & 110 & 5 to 12 & $\begin{array}{l}\text { Fichtler et al. } \\
2004[28]\end{array}$ \\
\hline \multirow[t]{2}{*}{$\begin{array}{l}\text { Brachystegia } \\
\text { spiciformis }\end{array}$} & $\begin{array}{l}\text { Namibia, } \\
\text { Zambia, } \\
\text { Tanzania }\end{array}$ & Rainfall (+); ENSO (-) & 149 & 9 to 34 & $\begin{array}{l}\text { Trouet et al. } \\
2010[34]\end{array}$ \\
\hline & Zambia & $\begin{array}{l}\text { December \& January } \\
\text { rainfall }(+) \text {; } \\
\text { Temperature }(-)\end{array}$ & 63 & 13 to 16 & $\begin{array}{l}\text { Trouet et al. } \\
2006[33]\end{array}$ \\
\hline $\begin{array}{l}\text { Isoberlinia } \\
\text { tomentosa }\end{array}$ & Tanzania & $\begin{array}{l}\text { Rainfall; } \\
\text { Temperature SOI-value }\end{array}$ & 38 & 8 & $\begin{array}{l}\text { Trouet et al. } \\
2001 \text { [32] }\end{array}$ \\
\hline
\end{tabular}

Given that Pterocarpus angolensis has been used successfully in Zimbabwe to create chronologies (Table 2), a preliminary analysis of the very limited data from the Botswana field sites was used to 
explore the potential for further collection and analysis. The two cores of $\mathrm{P}$. angolensis sampled from the same site (near Tsodilo, Figure 1) were visually cross-dated and the computer program COFECHA [49] was used to identify measureable cross-dating and establish the potential for future chronology building when a sufficient sample can be collected. Since the sample depth was limited the two ring width series were standardized and detrended independently using ARSTAN [50]. ARSTAN produces a standardized tree ring series using biweight robust estimation.

\subsection{CASA Model to Derive NPP}

\subsubsection{Remote Sensing Data}

The Carnegie-Ames-Stanford Approach (CASA) was used to predict monthly NPP fluxes for the period 1982-2010, based on the recently released Global Inventory Monitoring and Modeling System (GIMMS3g) normalized difference vegetation index (NDVI) data and the global high-resolution climate data [51]. The GIMMS3g NDVI dataset is currently the longest temporal extent of a vegetation index available and was generated from the AVHRR data (onboard NOAA 7, 9, 11, 14, 16, 17 and 18). Corrections were applied to this dataset for volcanic aerosols (1982-1984; 1991-1994) (see Fensholt et al. (2013) [52]; for orbital drift correction [53], and for calibration loss and sensor degradation [54]. The spatial resolution of this dataset is $8 \mathrm{~km}$ by $8 \mathrm{~km}$, and we aggregated the 15-day maximum NDVI value reported into a monthly observation using the maximum value composition. This $0.083^{\circ}$ cell size was then averaged to create new pixels at $0.5^{\circ}$ to match the climate datasets needed to run the NPP model.

\subsubsection{Climate Data}

The Climate Research Unit data at East Anglia University were used to represent the high-resolution gridded climate data needed by the CASA model (data version: CRU TS 3.20). These datasets were constructed from monthly observations from meteorological stations across the globe [55]. Monthly precipitation and temperature datasets were used in the calculations of temperature and water stress scalar in the CASA model. The National Center for Environmental Prediction (NCEP) DOE reanalysis II data were used to obtain the surface solar radiation dataset (downward shortwave radiation). This data was in a global T62 Gaussian grid and was interpolated to a regular grid cell size of $0.5^{\circ}$.

\subsubsection{Land Cover and Soil Data}

Vegetation data were determined based on the year 2000 global land cover product from the Joint Research Center of the European Commission (created from 1999 to 2000 VEGETATION sensor on SPOT-4) [56]. Data resolution was $1 \mathrm{~km}$ so these were aggregated to the most common land cover class within the 56 by 56 pixel area which made up each $0.5^{\circ}$ grid. The soil texture data were obtained from the Zobler soil texture class map (Distributed Active Archive Center Data DAAC download from Oak Ridge National Library). This was based on the FAO soil map of the world and the spatial scale was $1^{\circ}$ so to reduce to $0.5^{\circ}$ each grid was split into 4 identical $0.5^{\circ}$ by $0.5^{\circ}$ grid cells. 


\subsubsection{CASA Model Description and Evaluation}

Potter et al. (1993) [51] first introduced the CASA model and can be referred to for detailed descriptions. CASA calculates seasonal flow of carbon between the terrestrial biosphere and atmosphere, and it does this across a number of different temporal and spatial resolutions. Its main advantage is that it can incorporate remotely sensed information to calculate NPP and carbon turnover. This model does so through a mechanistic, CENTURY-like plant and soil carbon cycling model [57]. The model used created a global NPP dataset from which we subset this study region. This global extent was necessary to allow us to better evaluate the model performance with a series of eddy covariance flux data (Ameriflux and European sites) and six BigFoot sites [58,59], and results compared very closely, although model data was usually slightly lower, which is not too surprising given a tower to grid cell comparison. The model has been used globally and was thus considered an excellent source to derive NPP data for this research [57]. NPP was calculated rather than using raw NDVI data as it was felt this would better represent and link to actual tree growth as measured by the dendrochronology data.

Using all of these techniques in concert (precipitation analysis, satellite derived NPP data and dendrochronology's from across the region), we can start to evaluate the details of the time-series for the specific tree ring sample locations, but also for a broader spatial evaluation we can scale to the landscape-level for a wider interpretation of overall vegetation change, not just tree growth. Such extensive spatial and temporal integration offers a model approach for integrating satellite with tree ring data.

\section{Results and Discussion}

\subsection{Precipitation Change}

Mean annual depth of precipitation input to the entire Okavango basin, expressed as deviations from the 50-year median (Figure 4a), indicates the major global climate shift in the mid-1970s identified by many researchers [38-42]. The shift is contemporaneous to changes in circulation of the North Pacific, and the way in which ENSO events evolve, particularly their interaction with the Indian Ocean [40,41]. This (Figure 4) exhibits considerable inter-annual variability of input to the Okavango, superimposed upon a consistent decline centered on the 1970s. A hypergeometric test shows that the number of above-median years on the Okavango (11), 1951-1970, is significantly greater than expected at random $(p=0.10$ level), and the number of below median years fewer. The basin experiences 12 below-median years (sig. 0.10) in the period 198-12000. Gaughan and Waylen (2012) [45] report that the strength of this change increases from west to east, perhaps indicative of the changing influence of ENSO events, many of which (1965-1966, 1972-1973,1982-1983, 1992-1993) seem to be reflected more strongly in the eastern than the western Okavango. For the station data closest to our sampling site, Shakawe, we see a declining trend of mean annual precipitation across this time period, and this station data will be linked directly to the tree core and remotely sensed variables for the same region. 
Figure 4. Annual precipitation for (a) Deviations from the 1951-2005 median annual precipitation for the Okavango drainage basin overall, and (b) Shakawe station precipitation data from 1951 to 2005.

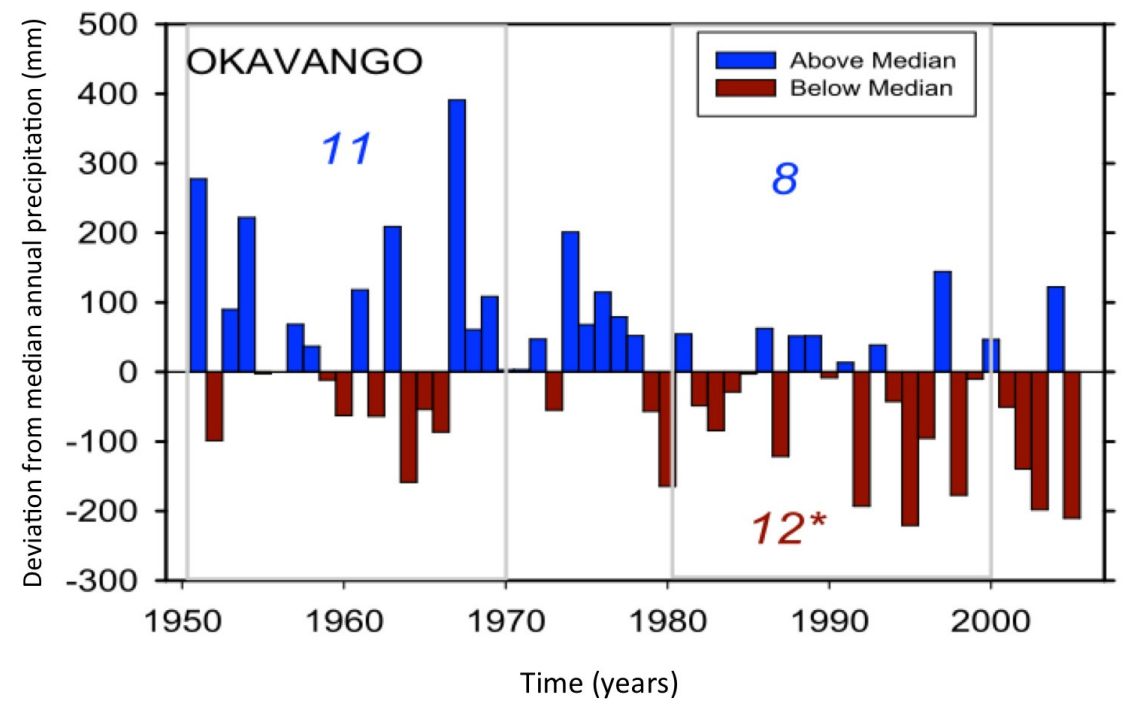

(a)

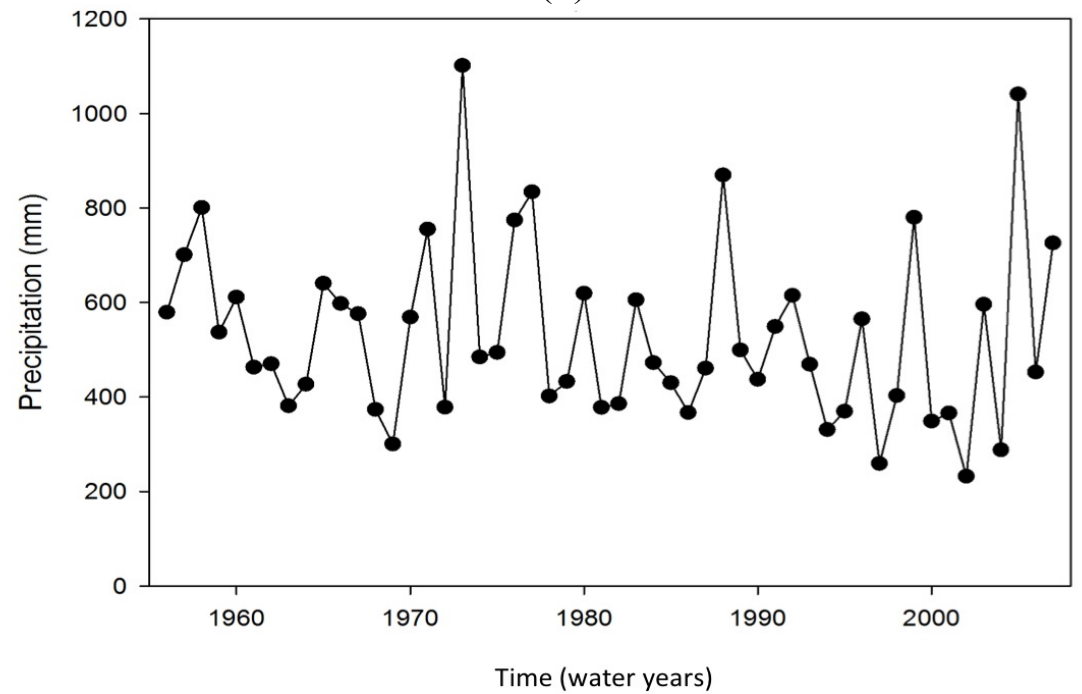

(b)

\subsection{Dendrochronology}

\subsubsection{Comparison to the Literature and to Available Published Tree Core data}

Previous tree ring studies have shown the dendroclimatological potential for several locally common species including; Burkea africana [28], Pterocarpus angolensis [28,31,60], Brachystegia spiciformis [32,34], and Isoberlinia tomentosa [32] (Table 2). Of these species, Pterocarpus angolensis not only has clearly identifiable growth rings but has also been shown to have growth synchronous with the seasonality of rainfall in neighboring western Zimbabwe [30]. Stands of $P$. angolensis 100's of kms apart in Zimbabwe exhibited the same climate response, which suggests that this species is potentially amenable to the construction of a long-term chronology (Figure 5). The same species gave rise to a 200-year chronology from Zimbabwe, Therrell et al. (2006) [31], which 
correlated growth response with summer rainfall over a 47-year period. ENSO signals and decadal drought patterns were also derived and confirmed. In Namibia, Fichtler et al. (2004) [28] constructed site specific chronologies for P. angolensis and Burkea africana, with the latter exhibiting positive sensitivity to precipitation, and both species being negatively correlated with temperatures. In the tropics, precipitation and temperatures are generally negatively correlated [61], which, validates the focus on precipitation patterns and their temporal changes. Growth of Brachystegia spiciformis, a dominant species of the miombo woodlands, showed a negative correlation with ENSO in south central Africa based upon chronologies of between 43 and 149 years [34] (Table 2), suggesting that longer chronologies developed from multiple species will allow for the temporal investigation of precipitation variability in the region. Therrell et al. (2006) [31] (Table 2) also found evidence of a decline in precipitation in Zimbabwe and associated decline in tree core growth rates, from the 1960s through the 1990s, similar to other Zimbabwe forests (Figure 5). However, they also caution the need for additional tree-ring data to confirm the growth signatures across the landscape.

Figure 5. Standardized (ARSTAN) tree ring chronologies for the Pterocarpus species in Zimbabwe from Mzola Forest, from Mushove et al. [62] and Sikumi Forest, from Stahle et al. [60] (data downloaded from the International Tree-Ring Data Bank).

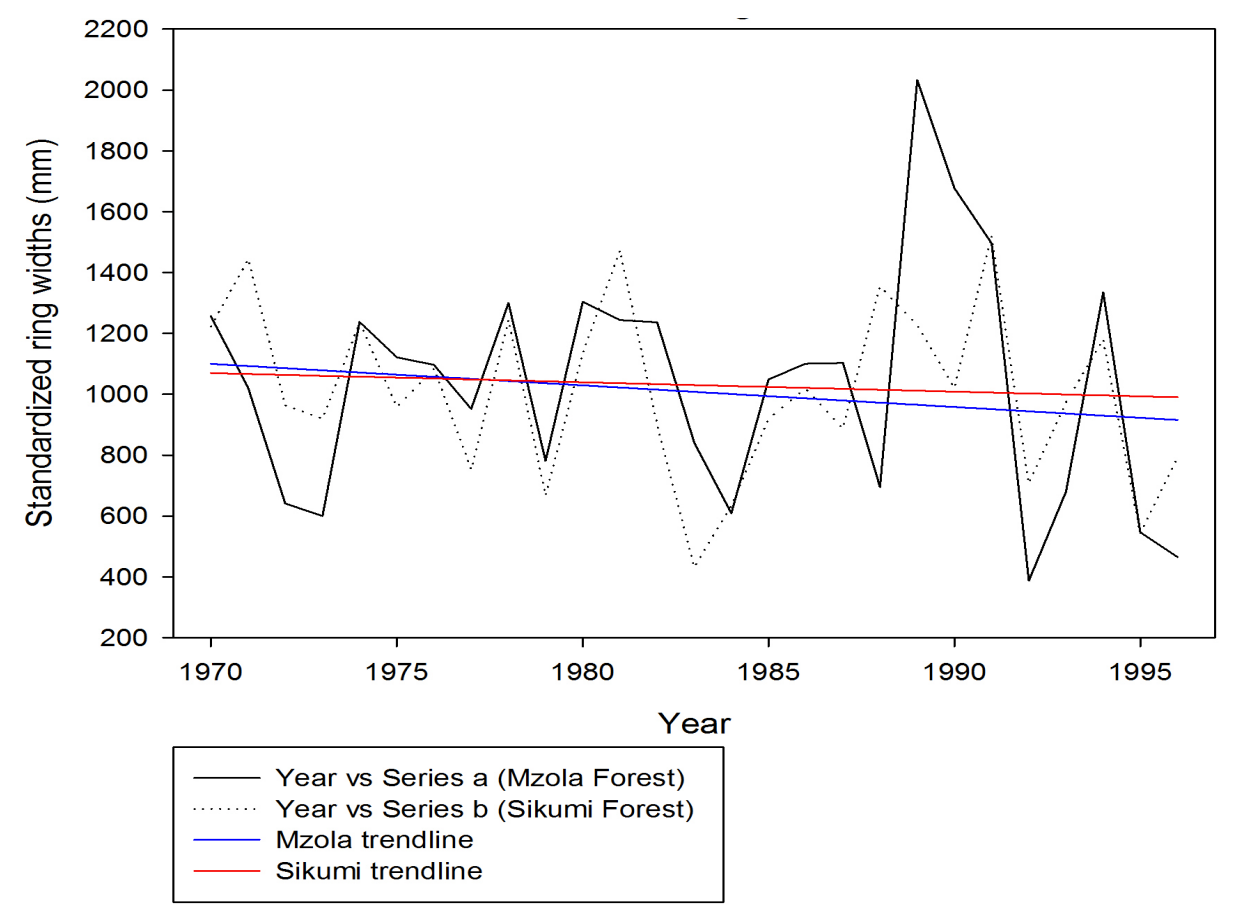

\subsubsection{Tree Ring Analysis from Sampled Cores}

The three P. angolensis cores in this study: Pa6 (43 years); Pa18 (71 years); and Pa19 (57 years), were all collected within the study area with Pa18 and Pa19 collected at the same site, near the site of Tsodilo Hills, Botswana (Figure 1). No comparable chronology exists within Botswana. The number of cores suitable for analysis collected in 2011 was too small for chronology building, and as a result initial analyses are restricted to exploratory correlations between precipitation (Shakawe) and the standardized ring width data. 
Using COFECHA the initial intercorrelation for Pt18 and Pt19 was fairly low, at 0.28 over a 72-year span. But the segment of the cores (1965-1994), relating to the drought period in the Shakawe precipitation data, had a higher intercorrelation of 0.49 , showing promise for increased synchronicity with more cores over a longer time period. Using the detrended growth increments for both cores a declining growth trend in the 1970s and 1980s is clearly evident (Figure 6), correlating with the noted precipitation decline in the Shakawe station precipitation data (Figure $4 \mathrm{~b}$ )

Figure 6. Standardized growth for Pterocarpus angolensis, Tsodilo Hills, Botswana. Hypothesized climate shift to dryer conditions in the early 1970s. Blue trend line indicated the mirrored patterns of decreased growth and decreased precipitation for (a) tree chronology Pt 18 and (b) tree chronology Pt 19.

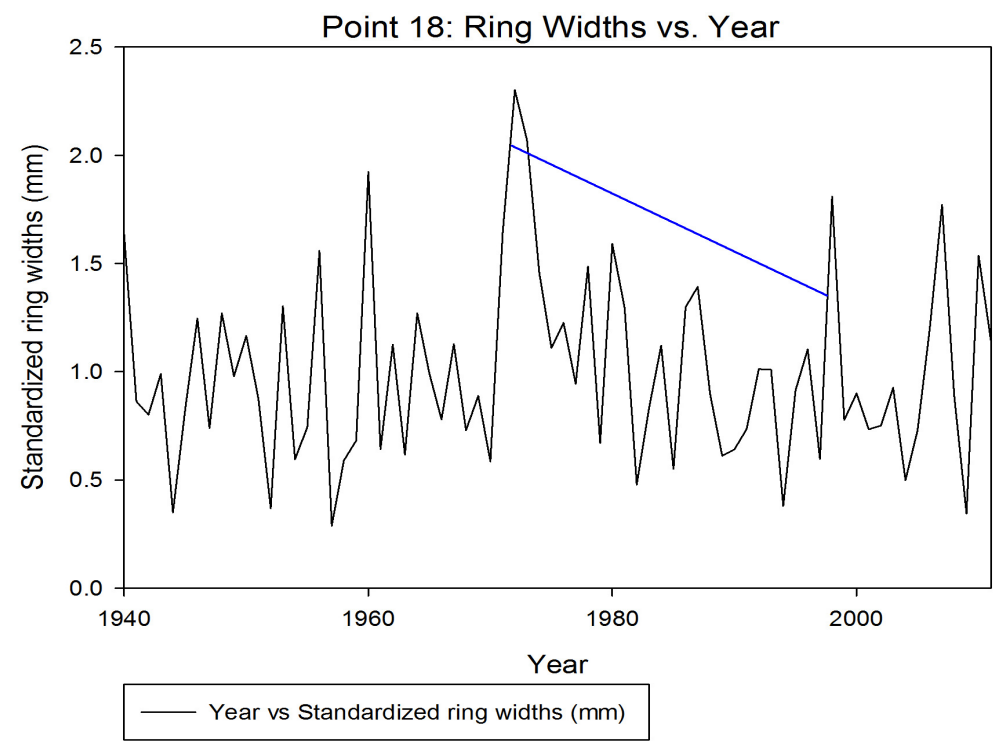

(a)

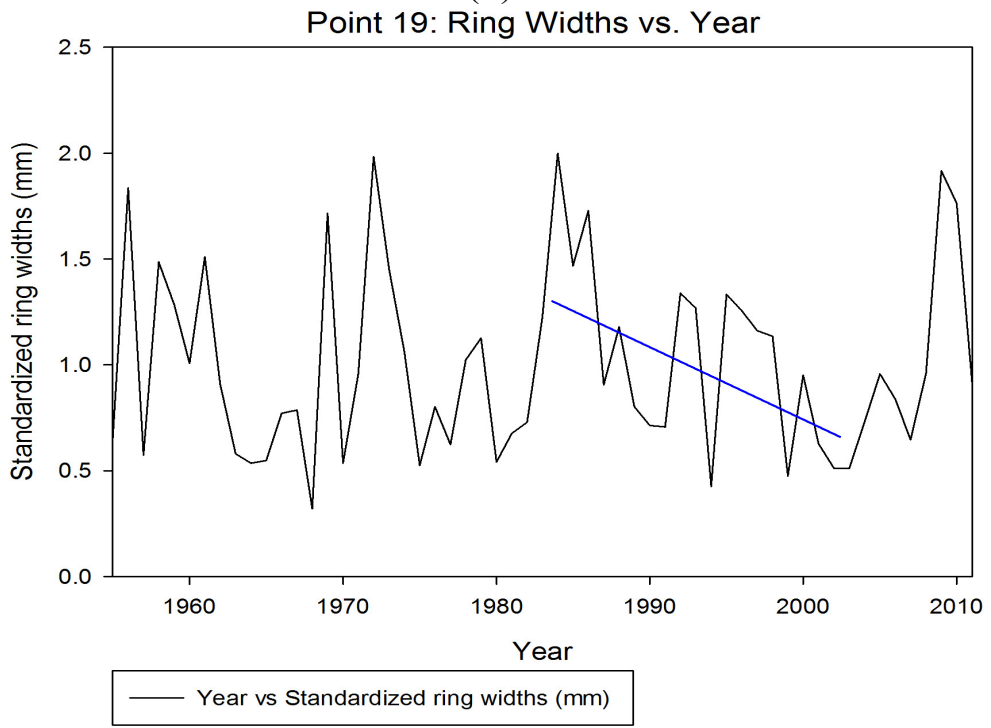

(b) 


\subsection{NPP Analysis}

Within the study area (Figure 7), we see a decline in NPP as we move south, that is strongly associated with precipitation (Figure 1). Given this is a water limited savanna system this pattern is expected. In terms of changes in NPP across the study period 1982-2010, we can see that while overall patterns show a significant decline in NPP (Figure 7b) there is also a region in the southernmost region, where precipitation totals around 450-550 annually or within the actual Delta area in the Okavango, where NPP values have increased across this time period. In terms of linking to our tree ring data, our region where our trees were cored (Figure 1) falls into the decreasing trends of NPP and higher MAP. As such these patterns do match the tree rings in terms of decreasing growth. Along with the declines in precipitation values (Figure 4) across this region for the same time period, we can hypothesize with some degree of certainty that decreasing precipitation has resulted in decreased tree growth and more regionally, NPP values overall.

Figure 7. Spatial pattern of mean aggregated NPP of water year and changing trends in NPP from 1982 to 2010. Positive Kendall tau values indicate an increase in NPP at the 0.05 level of significance, while negative Kendall tau value represents a decrease in NPP at the 0.05 level of significance.
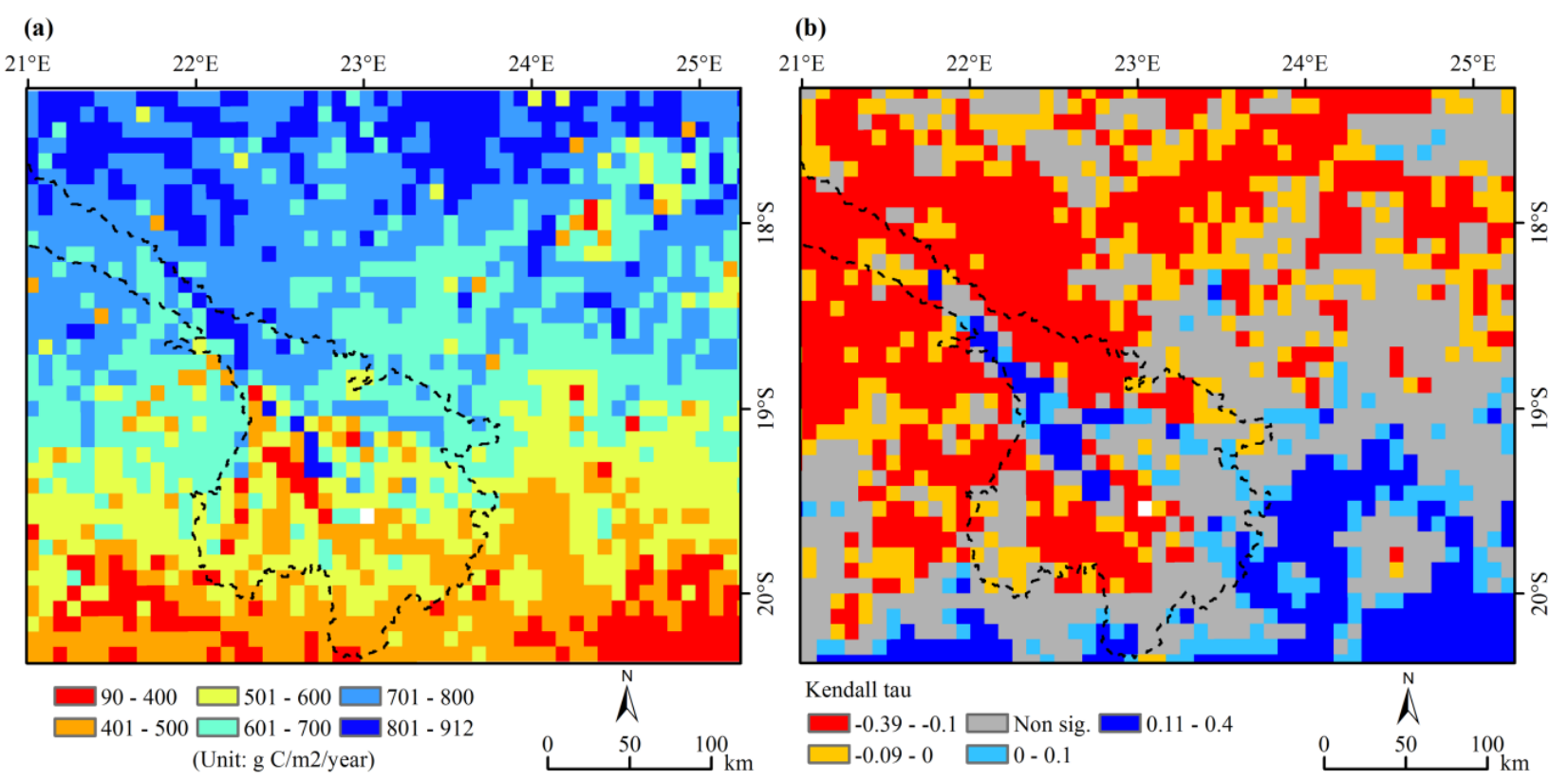

The standardized tree ring growth widths for both Pa18 and Pa19 were positively correlated with the annual NPP (Figure 8). As such, the lower NPP values at the pixel level are associated with slower tree growth within a given time period and vice versa. Correlation values were quite low (around +0.2 ) and this relates to the understudied nature of the data. Specifically, it must be noted that this is a general trend to be viewed as we do not know true tree ring age but only approximate year, due to the use of trees cores as opposed to a full chronology. Future research would aim to improve upon this data with full species chronologies which can be lined up to individual years on NPP growth. However, despite limitations regarding year to year correlations, overall trends are clear and indicate a decline in NPP over time and a decline in tree ring growth. As such, the lower NPP values at the pixel 
scale are likely associated with slower tree growth within the given time period, and though future research is needed to further elucidate this relationship, the findings presented here suggest that the linkages across the different data series hold great potential.

Time series analysis shows clearly that the tree cores are declining $(r=-0.54$ and $r=-0.58)$, as has precipitation $(\mathrm{r}=-0.33)$ (Figure 4). The trends for NPP also reflect this same pattern across much of the study region (except for areas of the lowest MAP and within the actual delta). This would match other research looking at longer-term climate change, which has found that dry spells in past climates have resulted in forest decline [10] and also often a related increase in shrub vegetation [11]. As such, the 30-50 year dry period which this region has experienced (Figure 4), may also be showing similar trends, with decreased tree growth, and potentially an increase in shrub/bush (Figures 7 and 8). More fieldwork is essential to test this hypothesis, especially an increase in the number of tree cores upon which to develop chronologies, but these initial results do support this preliminary conclusion.

Figure 8. Plot of NPP versus tree cores.

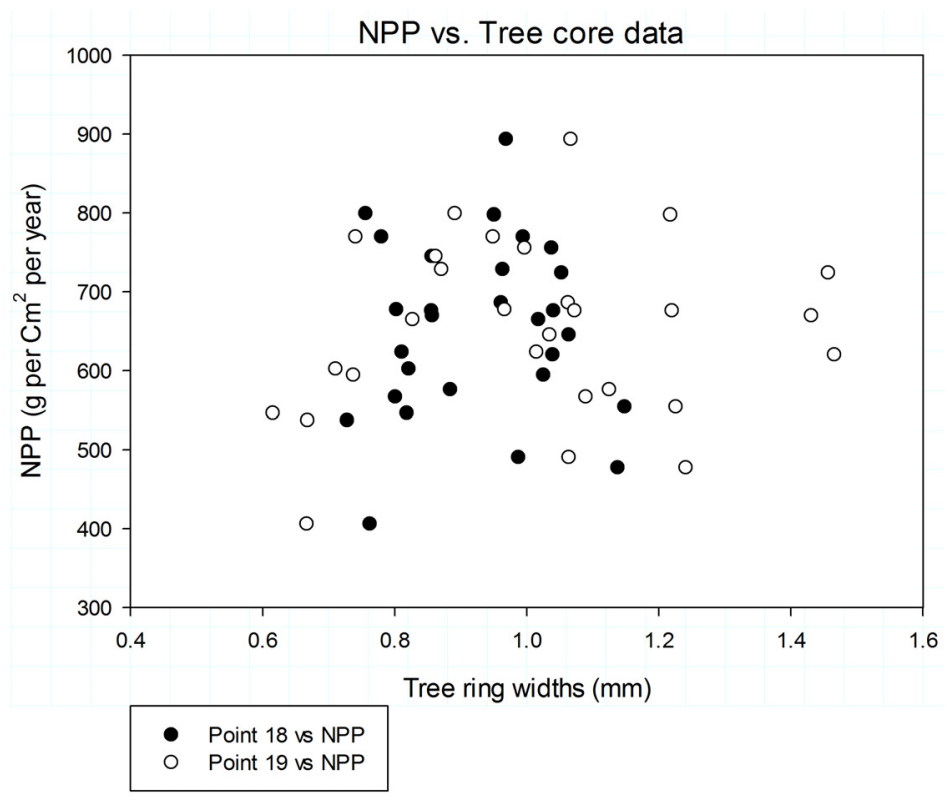

\section{Conclusions}

We hypothesized that vegetation change and climate can be linked directly across a longer time series by integrating analyses of remote sensing, precipitation records and dendrochronology across this region. Patterns of large-scale atmospheric circulation determine the distribution of precipitation and temperatures and therefore vegetation coverage. Thus identification and understanding of recurrent (temporal) and coherent (spatial) patterns of precipitation are central to the interpretation of variations (intra- and inter- annual) and low frequency persistence (inter-decadal) within the newly derived time series of NPP. Understanding temporal and spatial connections between global climate fluctuations and regional precipitation can lead to better modeling of the vegetation system (e.g., links to past periods of scarce written records, through dendrochronology and forecasts of likely impacts on vegetation of climate change) and thereby inform improved land use planning, management and policy, on both regional and local scales. However, the linkage between precipitation and vegetation in 
savanna regions is neither simple nor linear, involving thresholds, equilibrium states and the potential compounded impacts of fire, humans and herbivory [26]. Additionally, the dearth of long term standardized climate and vegetation records further hinders the development of precipitation climate linkages and necessitates the combining of varied data sources to generate a temporally and spatially extensive record of climate and vegetation linkages.

Dendrochronolgy and remote sensing, via the use of the CASA model to derive satellite based NPP data, allow for a truly multi-scalar (temporal and spatial) analysis and enable the determination of the types of responses that individual species have to changes in climate, which yield broader landscape shifts in vegetation composition and patterns. This analysis offers a first attempt at a standardized approach to measuring vegetation responses to changing climates in the region. Individual tree growth patterns appear to be directly related to patterns of precipitation across this landscape and in addition, the larger landscape-level response and vegetation dynamics, also suggest a similar decline in NPP for most of this region (Figure 8). To further evaluate these trends more work and fieldwork is essential, though the analyses presented here demonstrate that the integration of climate-vegetation-remote sensing analyses do provide a unique set of tools with which to approach these research challenges. Future research will more fully elucidate these patterns and better identify the drivers of change.

There is no doubt that over long periods of time vegetation communities respond to climate changes by range shifts or species compositional changes. This research linked the dynamics of the climate-vegetation system explicitly to current and past climate. Triangulating results from each approach described here we determined that the climate vegetation associations are both statistically and physically significant across the study landscape, and that both current and future climate changes may be of a magnitude that will result in considerable effects on savanna and woodland vegetation, land use choices, and socio-ecological functioning. Thus, we add to the growing knowledge base in dryland ecology that investigates the impacts of current climate variability and change on natural ecosystems with the eventual goal of preparing humans to adapt in the event that plants and their associated soils fail to adapt to the rapidly changing conditions or land-use pressures. Further, the proposed and demonstrated integration of dendrochronology, remote sensing of inputs to NPP modeling, with respect to climate change, and associated results, offers useful insight for land managers and policy makers to consider as they develop strategies for monitoring and interacting with environmental change.

\section{Acknowledgments}

This study was funded by NASA LCLUC Project \# NNX09AI25G. Titled "The Role of Socioeconomic Institutions in Mitigating Impacts of Climate Variability and Climate Change in Southern Africa" PI: Jane Southworth. We would also like to thank the five anonymous reviewers who provided useful comments which were fully incorporated into this manuscript. The reviewers significantly improved the overall quality of this paper.

\section{Conflict of Interest}

The authors declare no conflict of interest. 


\section{References and Notes}

1. Intergovernmental Panel on Climate Change (CCI). The Physical Science Basis, Contribution of Working Group I to the Fourth Assessment Report of the Intergovernmental Panel on Climate Change; Cambridge University Press: Cambridge, UK, 2007.

2. Davis, M.B. Climate Change and the Survival of Forest Species. In The Earth in Transition: Patterns and Processes of Biotic Impoverishment; Woodwell, G.M., Ed.; Cambridge University Press: Cambridge, UK, 1990; pp. 99-110.

3. Malcolm, J.R.; Markham, A.; Neilson, R.P.; Garaci, M. Estimated migration rates under scenarios of global climate change. J. Biogeogr. 2002, 29, 835-849.

4. Houghton, J. Global Warming: The Complete Briefing; Cambridge University Press: Cambridge, UK, 1997.

5. Delcourt, P.A.; Delcourt, H.R. Late-quaternary dynamics of temperate forests: Applications of paleoecology to issues of global environmental change. Quat. Sci. Rev. 1987, 6, 129-146.

6. Davis, M.B.; Shaw, R.G. Range shifts and adaptive responses to quaternary climate change. Science 2001, 292, 673-679.

7. Scott, L. Late quaternary forest history in Venda, Southern Africa. Rev. Paleobot. Palynol. 1987, $53,1-10$.

8. Scott, L. Climatic conditions in Southern Africa since the last glacial maximum, inferred from pollen analysis. Paleogeogr. Paleoclim. Paleoecol. 1989, 70, 345-353.

9. Dupont, L.M.; Caley, T.; Kim, J-H.; Castaneda, I.; Malaize, B.; Giraudeau, J. Glacial-interglacial vegetation dynamics in South Eastern Africa depend on sea surface temperature variations in the West Indian Ocean. Clim. Past Discuss. 2011, 7, 2261-2296.

10. Ekblom, A. Forest-savanna dynamics in the coastal lowland of southern Mozambique since C. AD 1400. The Holocene 2008, 18, 1247-1257.

11. Scott, L.; Bousman, C.B. Palynological analysis of hyrax middens from Southern Africa. Paleogeogr. Paleoclim. Paleoecol. 1990, 76, 367-379.

12. Kambatuku, J.R.; Cramer, M.D.; Ward, D. Intraspecific competition between shrubs in a semi-arid savanna. Plant Ecol. 2011, 212, 1701-1713.

13. Scholes, R.; Walker, B. An African Savanna: Synthesis of the Nylsvley Study; Cambridge University Press: New York, NY, USA, 1993.

14. Hanan, N.; Lehmann, C. Tree-Grass Interactions in Savannas: Paradigms, Contradictions, and Conceptual Models. In Ecosystem Function in Savannas; Hill, M., Hanan, N., Eds.; Taylor and Francis Group: Boca Raton, FL, USA, 2010; pp. 39-53.

15. Ellis, J.E.; Swift, D.M. Stability of African pastoral ecosystems: Alternate paradigms and implications for development. J. Range Manag. 1988, 41, 450-459.

16. Zen, N.; Neelin, D. The role of vegetation-climate interaction and interannual variability in shaping the African savanna. J. Climate 2000, 13, 2665-2670.

17. Meyer, K.M.; Wiegand, K.; Ward, D.; Moustakas, A. The rhythm of savanna patch dynamics. J. Ecol. 2007, 95, 1306-1315.

18. Gillson, L.; Hoffman, M.T. Rangeland ecology in a changing world. Science 2007, 315, 53-54.

19. Blaikie, P.; Brookfield, H. Land Degradation and Society; Methuen: London, UK, 1987. 
20. Johnson, D.L.; Lewis, L. Land Degradation: Creation and Destruction; Blackwell: Oxford, UK, 2004.

21. Thomas, D.S.G.; Twyman, C. Good or bad rangeland? Hybrid knowledge, science and local understandings of vegetation dynamics in the Kalahari. Land Degrad. Dev. 2004, 15, 215-231.

22. Ringrose, S.; Matbeson, W.; Tempest, F.; Boyle, T. The development and causes of range degradation features in south-east Botswana using multi-temporal Landsat MSS imagery. Photogramm. Eng. Remote Sens. 1990, 56, 1253-1262.

23. Barnes, R.F.W. The effect of elephant browsing on woodlands in a Tanzanian National Park: Measurements, models and management. J. Appl. Ecol. 1983, 20, 521-539.

24. Baxter, P.W.J.; Getz. W.M. A model-framed evaluation of elephant effects on tree and fire dynamics in African Savannas. Ecol. Appl. 2005, 15, 1331-1341.

25. Ntumi, C.P.; van Varde, R.J.; Fairall, N.; de Boer, W.F. Use of space and habitat by elephants in the Maputo Elephant Reserve, Mozambique. South. Afr. J. Wildl. Res. 2005, 35, 139-146.

26. Campo-Bescos, M.; Munoz-Carpena, R.; Kaplan, D.; Southworth, J.; Zhu, L.; Waylen, P. Beyond precipitation: Physiographic gradients dictate the relative importance of environmental drivers on savanna vegetation. PLOS One 2013, 8, e72348.

27. Sankaran, M.; Hanan, N.; Scholes, R.J.; Ratnam, J.; Augustine, D.J.; Cade, B.S.; Gignoux, J.; Higgins, S.I.; Roux, X.L.; Ludwig, F.; et al. Determinants of woody cover in African savannas. Nature 2005, 438, 1038.

28. Fichtler, E.; Trouet, V.; Beeckman, H.; Coppin, P.; Worbes, M. Climatic signals in tree rings of Burkea Africana. Trees 2004, 18, 442-451.

29. Rozendaal, D.M.A.; Zuidema, P.A. Dendroecology in the tropics: A review. Trees 2010, 25, 3-16.

30. Stahle, D.W.; Mushove, P.T.; Cleaveland, M.K.; Roig, F.; Haynes, G.A. Management implications of annual growth rings in Pterocarpus angolensis from Zimbabwe. Forest Ecol. Manag. 1999, 124, 217-229.

31. Therrell, M.D.; Stahle, D.W.; Ries, L.P.; Shugart, H.H. Tree-ring reconstructed rainfall variability in Zimbabwe. Clim. Dyn. 2006, 26, 677-685.

32. Trouet, V.; Haneca, K.; Coppin, P.; Beeckman, H. Tree ring analysis of Brachystegia spiciformis and Isoberlinia tomentosa: Evaluation of the ENSO-signal in the Miombo woodland of Eastern Africa. IAWA J. 2001, 22, 385-399.

33. Trouet, V.; Coppin, P.; Beeckman, H. Annual growth ring patterns in Brachystegia spiciformis reveal influence of precipitation on tree growth. Biotropica 2006, 38, 375-382.

34. Trouet, V.; Esper, J.; Beeckman, H. Climate/growth relationships of Brachystegia spiciformis from the miombo woodland in south central Africa. Dendrochronologia 2010, 28, 161-171.

35. Gieske, A. Modelling outflow from the Jao/Boro River system in the Okavango Delta, Botswana. J. Hydrol. 1997, 193, 214-239.

36. McCarthy, T.S. The great inland deltas of Africa. J. Afr. Earth Sci. 1993, 17, 275-291.

37. Ellery, K.; Ellery, W.N.; Rogers, K.H.; Walker, B.H. Water depth and biotic insulation: major determinants of backswamp plant community composition. Wetl. Ecol. Manag. 1991, 1, 149-162.

38. Hare, S. R.; Mantua, N.J. Empirical evidence for North Pacific regime shifts in 1977 and 1989. Prog. Oceanogr. 2000, 47, 1030-1045.

39. Mason, S. El Niño, climate change and Southern African climate. Environmetrics 2001, 12, 327-345. 
40. Chavez, F.P.; Ryan, J.; Lluta-Cota, S.E.; Niquen, M. From anchovies to sardines and back: Multidecadal change in the Pacific Ocean. Science 2003, 299, 217-221.

41. Shi, G.; Ribbe, J.; Cai, W.; Cowan, T. Multidecadal variability in the transmission of ENSO signals to the Indian Ocean. Geophys. Res. Lett. 2007, 34, L09706.

42. Manatsa, D.; Matarira, C.H.; Mukwada, G. Relative Impacts of ENSO and Indian Ocean dipol/zonal mode on east SADC rainfall. Int. J. Climatol. 2011, 31, 558-577.

43. Ropelewski, C.F.; Halpert, M.S. Halpert global and regional scale precipitation patterns associated with the El Niño/Southern Oscillation. Mon. Weather Rev. 1987, 115, 1606-1626.

44. Waylen, P.; Henworth, S. A note on the timing of precipitation variability in Zimbabwe as related to the Southern Oscillation. Int. J. Climatol. 1996, 16, 1137-1148.

45. Gaughan, A.E.; Waylen, P.R. Spatial and temporal precipitation variability in the Okavango-Kwando-Zambezi catchment, Southern Africa. J. Arid Environ. 2012, 82, 19-30.

46. Matsuura, K.; Willmott, C. Terrestrial Air Temperature and Precipitation: 1900-2006 Gridded Monthly Time Series, Version 1.01; University of Delaware: Newark, DE, USA, 2007.

47. Speer, J.H. Fundamentals of Tree-Ring Research; University of Arizona Press: Tucson, AZ, USA, 2010.

48. Stokes, M.A.; Smiley, T.L. An Introduction to Tree-Ring Dating; University of Chicago Press: Chicago, IL, USA, 1968.

49. Holmes, R.L. Computer-assisted quality control in tree-ring dating and measurement. Tree-Ring Bull. 1983, 43, 69-78.

50. Cook, E.R.; Holmes, R.L. Program ARSTAN Users Manual; Laboratory of Tree-Ring Research, University of Arizona: Tucson, AZ, USA, 1984.

51. Potter, C.S.; Randerson, J.T.; Field, C.B.; Matson, P.A.; Vitousek, P.M.; Mooney, H.A.; Klooster, S.A. Terrestrial ecosystem production: a process model based on global satellite and surface data. Glob. Biogeochem. Cy. 1993, 7, 811-841.

52. Fensholt, R.; Rasmussen, K.; Kaspersen, P.; Huber, S.; Horion, S.; Swinnen, E. Assessing land degradation/recovery in the African Sahel from long-term earth observation based primary productivity and precipitation relationships. Remote Sens. 2013, 5, 664-686.

53. Tucker, C.; Pinzon, J.; Brown, M.; Slayback, D.; Pak, E.; Mahoney, R.; Vermote, E.; El Saleous, N. An extended AVHRR 8-km NDVI dataset compatible with MODIS and SPOT vegetation NDVI data. Int. J. Remote Sens. 2005, 26, 4485-4498.

54. Cook, B.; Pau, S. A global assessment of long-term greening and browning trends in pasture lands using the GIMMS LAI3g dataset. Remote Sens. 2013, 5, 2492-2512.

55. Harris, I.; Jones, P.D.; Osborn, T.J.; Lister, D.H. Updated high-resolution grids of monthly climatic observations-The CRU TS3.10 dataset. Int. J. Climatol. 2013, doi: 10.1002/joc.3711.

56. European Commission (JRC). Global Land Cover 2000 Database. Available online: http://bioval.jrc.ec.europa.eu/products/glc2000/glc2000.php (accessed on 18 March 2013).

57. Field, C.B.; Randerson, C.J.T.; Malmström, M. Global net primary production: combining ecology and remote sensing. Remote Sens. Environ. 1995, 51, 74-97.

58. Gower, S.T.; Kirschbaum, A.A. BigFoot Field Data for North American Sites, 1999-2003. Data Set; Oak Ridge National Laboratory Distributed Active Archive Center: Oak Ridge, TN, USA, 2008. 
59. Potter, C.; Klooster, S.; Genovese, V. Net primary production of terrestrial ecosystems from 2000 to 2009. Clim. Chang. 2012, 115, 365-378.

60. Stahle, D.G.H.; Klimowicz, J.; Muleya, S. Pterocarpus angolensis Chronology, Zimbabewe; International Tree-Ring Data Bank (ITRDB). Available online: http://www.ncdc.noaa.gov/paleo/ treering.html (accessed on 18 March 2013).

61. Webster, P.J. The role of hydrological processes in ocean-atmosphere interactions. Rev. Geophys. 1994, 32, 427-476.

62. Mushove, P.; Stahle, D.W.; Cleaveland, M.K. Pterocarpus angolensis Chronology, Zimbabewe; International Tree-Ring Data Bank (ITRDB). Available online: http://www.ncdc.noaa.gov/paleo/ treering.html (accessed on 18 August 2013).

(C) 2013 by the authors; licensee MDPI, Basel, Switzerland. This article is an open access article distributed under the terms and conditions of the Creative Commons Attribution license (http://creativecommons.org/licenses/by/3.0/). 